\title{
Perilaku Generasi Milenial dalam Menggunakan Aplikasi Go-Food
}

\author{
Syarif Hidayatullah, Abdul Waris *, Riezky Chris Devianti, \\ Syafitrilliana Ratna Sari, Irawan Ardi Wibowo, Pande Made PW \\ Fakultas Ekonomi dan Bisnis Universitas Merdeka Malang, Malang \\ *waris_sip@yahoo.com
}

\begin{abstract}
In era of industry 4.0 revolution, the development of information technology makes the lifestyle changes of modern generation (millennial generations born between 1980 to 2000). This aims of this study is to analyze how the behavior of millennial generations in using Go-food applications. The characteristics of the millennial generation in this study are: 1) user generated content (UGC); 2) take advantage of technology and information; 3) consumptive behavior; 4) tends lazy. The data analysis uses a descriptive analysis and linear regression analysis. The results of data analysis show that: 1) the millennial generation's decision to use Go-food applications is influenced by behavior of millennial generation; and 2) millennial generation's behavior which has a dominant influence in making decision to use Go-food appications is consumptive behavior.
\end{abstract}

Keywords: Behavior, Go-food, Millennial Generation.

\section{PENDAHULUAN}

Pada era revolusi industri 4.0 saat ini, perkembangan teknologi informasi mulai dari smartphone hingga media sosial telah mengubah gaya hidup masyarakat hingga pada titik yang paling fundamental. Menurut McLuhan (1962) "inovasi dalam bidang teknologi informasi atau teknologi komunikasi memberi perubahan yang sangat besar terhadap kehidupan masyarakat". Dengan kemajuan teknologi yang telah mempermudah pekerjaan masyarakat baik secara langsung maupun tidak langsung telah merubah gaya hidup masyarakat. Perubahan gaya hidup mendorong masyarakat modern saat ini menjadi masyarakat yang cenderung konsumtif, Hal ini karena masyarakat membutuhkan kemudahan dalam segala aspek kehidupan dengan prinsip yang lebih praktis, sehingga dapat mempersingkat waktu dan tidak mengganggu pekerjaan.
Saat ini perubahan gaya hidup yang konsumtif sangat terlihat pada generasi modern atau yang biasa disebut dengan generasi milenial (Millennial Generation), generasi milenial merupakan generasi modern yang hidup di pergantian milenium. Secara bersamaan di era ini teknologi digital mulai merasuk ke segala sendi-sandi kehidupan. Generasi milenial atau yang disebut juga generasi $\mathrm{Y}$ ini lahir sekitar tahun 1980 sampai 2000. Jadi bisa dikatakan generasi milenial adalah generasi muda masa kini yang saat ini berusia sekitar 15-34 tahun. Kisaran usia tersebut sesuai dengan rata-rata usia mahasiswa yang sedang menempuh pendidikan di perguruan tinggi yaitu sekitar 19-34 tahun.

Pada era serba canggih saat ini, bisnis digital atau online mulai tumbuh termasuk di antaranya bisnis pemesanan makanan dimana kita bisa memesan makanan dengan 
menggunakan aplikasi yang tersedia pada smartphone. Memesan makanan dapat dilakukan dari mana saja dan kapan saja, tanpa harus datang ke toko atau ke mall secara langsung. Salah satu layanan jasa berbasis online saat ini yang dapat di manfaatkan untuk memesan makanan adalah Go-food. Go-food sendiri merupakan salah satu bentuk pelayanan jasa yang terdapat pada layanan jasa aplikasi Go-Jek.

Adapun yang menjadi tujuan dalam penelitian ini adalah untuk mengetahui apakah ada pengaruh dalam perilaku generasi milenial yang terdiri dari user generated content, memanfaatkan teknologi dan informasi, konsumtif dan perilaku yang cenderung malas terhadap keputusannya dalam menggunakan aplikasi Go-food untuk memenuhi kebutuhan makanya sehari-hari, serta untuk mengetahui variabel yang paling dominan berpengaruh terhadap keputusan dalam menggunakan aplikasi Go-food.

\section{Generasi Milenial}

Menurut Yuswohady dalam artikel Milennial Trends (2016) Generasi milenial (Millennial Generation) adalah generasi yang lahir dalam rentang waktu awal tahun 1980 hingga tahun 2000. Generasi ini sering disebut juga sebagai Gen-Y, Net Generation, Generation WE, Boomerang Generation, Peter Pan Generation, dan lain-lain. Mereka disebut generasi milenial karena merekalah generasi yang hidup di pergantian milenium. Secara bersamaan di era ini teknologi digital mulai merasuk ke segala sendi kehidupan.

Berdasarkan hasil penelitian dari Lancaster \& Stillman (2002) Generasi Y dikenal dengan sebutan generasi millenial atau milenium. Ungkapan generasi Y mulai dipakai pada editorial koran besar Amerika Serikat pada Agustus 1993. Generasi ini banyak menggunakan teknologi komunikasi instan seperti email, SMS, instant messaging dan media sosial seperti facebook dan twitter, IG dan lain-lain, sehingga dengan kata lain generasi $\mathrm{Y}$ adalah generasi yang tumbuh pada era internet booming.

Berdasarkan definisi tersebut dapat ditarik kesimpulan bahwa generasi milenial adalah generasi yang lahir diantara tahun 1980-2000 saat terjadi kemajuan teknologi yang pesat. Jika dilihat dari kelompok umur, generasi milenial merupakan generasi yang saat ini berusia dikisaran 15-34 tahun.

\section{Karakteristik Generasi Milenial}

Berdasarkan literatur dari artikel Hitss.com, diketahui ada beberapa macam karakteristik dari generasi milenial yaitu: 1) milenial lebih percaya user generated content (UGC) daripada informasi searah, 2) milenial lebih memilih ponsel dibanding TV, 3) miilenial wajib punya media sosial, 4) milenial kurang suka membaca secara konvensional, 5) milenial cenderung tidak loyal namun bekerja efektif, 6) milenial cenderung melakukan transaksi secara cashless, 7) milenial lebih tahu teknologi dibanding orang tua mereka, 8) milenial memanfaatkan teknologi dan informasi, 9) milenial cenderung lebih malas dan konsumtif, dan lain-lain.

Namun dalam penelitian ini akan membatasi ruang lingkup hanya pada beberapa karakteristik, yaitu milenial lebih percaya pada user generated content (UGC) daripada informasi searah, milenial memanfaatkan teknologi dan informasi, milenial cenderung lebih malas dan konsumtif karena karakteristik tersebut memenuhi kriteria pada penelitian terkait perilaku milenial terhadap keputusan menggunakan aplikasi Go-food. Berikut ini adalah penjelasan dari beberapa karakteristik tersebut yang digunakan untuk mengetahui keputusan dalam menggunakan aplikasi Gofood.

\section{Milenial lebih Percaya User generated content (UGC)}

Berdasarkan salah satunya studi yang dilakukan oleh Boston Consulting Group $(B C G)$ bersama University of Berkley tahun 2011 di Amerika. Studi ini mengambil tema American Millennials: Deciphering the Enigma Generation. Di tahun sebelumnya, Pew Research Center (2010) juga merilis laporan riset dengan judul Millennials: $A$ Portrait of Generation Next, Rahayu Aditya 
literature telah merangkum dan menjelaskan pengertian user generated content (UGC) dalam artikel pada hipwee.com bahwa kini sudah bukan jamannya lagi bagi kaum milenial untuk percaya pada produk iklan atau perusahaan besar. Bisa dikatakan kalau mereka sudah tidak percaya lagi kepada distribusi informasi yang bersifat satu arah. Mereka jauh lebih percaya pada user generated content (UGC) atau konten dan informasi yang dibuat oleh perorangan. Contohnya saja ketika ingin membeli sebuah produk, mereka tidak akan langsung membelinya hanya karena melihat iklan konvensional. Tapi mereka justru akan mencari tahu terlebih dahulu review atau testimoni yang dilakukan oleh orang lain di internet. Mereka pun juga tidak akan ragu membagikan pengalaman baik atau buruk yang mereka alami terhadap sebuah merek agar orang lain bisa mendapatkan informasi.

Metode user generated content (UGC) ini juga digunakan oleh para pebisnis khususnya yang bergerak pada bisnis online sebagai strategi dalam pemasaran produk kepada konsumen jaman sekarang yang mayoritas adalah milenial.

\section{Memanfaatkan Teknologi dan Informasi}

Karena lahir di era kemajuan teknologi, perilaku Gen Y ini amat sangat bergantung dengan teknologi. Mereka bergantung pada internet untuk mencari beragam informasi termasuk mengumpulkan informasi sebelum mengambil keputusan pembelian suatu produk atau menggunakan suatu jasa. Mengingat kelancaran dan kenyamanan milenial dengan teknologi dan informasi, mereka memiliki pandangan positif tentang bagaimana teknologi dan informasi memengaruhi kehidupan mereka daripada generasi sebelumnya.

Menurut Djoyohadikusumo

Pengertian teknologi sebagai bidang yang berkaitan erat dengan ilmu pengetahuan dan ilmu teknik atau rekayasa. Pada dasarnya dapat disimpulkan bahwa teknologi dapat dikatakan memiliki dua dimensi, yaitu dimensi teknik dan ilmu pengetahuan dimensi.

Menurut Cushing (1974) dalam buku Accounting Information System and Business Organization, Barry E. Cushing menyatakan bahwa informasi merupakan suatu hal yang menunjukkan hasil suatu proses pengolahan data. Hasil pengolahan data tersebut terorganisir dan mempunyai manfaat atau berguna bagi penerimanya.

Sehingga dapat ditarik kesimpulan bahwa generasi milenial sangat memanfaatkan teknologi dan informasi karena adanya kemajuan teknologi dan informsi dan generagi milenial dapat melakukan aktivitas menjadi sangat mudah, instan serta update dengan informasi terkini.

\section{Konsumtif}

Gaya hidup online sepertinya sudah menjadi bagian dari jiwa seorang milenial. Tidak heran berbagai iklan produk barang dan jasa tidak asing bagi milenial melalui berbagai platform media. Ajakan untuk berbelanja menggema sejak orang bangun tidur, beraktivitas, hingga saat kembali ke rumah. Tidak heran, mereka menjadi konsumtif. Generasi milenial lebih konsumtif dalam arti lebih senang menghabiskan uang untuk membeli suatu produk atau menggunakan jasa yang telah disediakan. Milenial merupakan konsumen yang mendominsi pasar saat ini. Tak heran ini merupakan peluang bisnis bagi pelaku bisnis khususnya bisnis online.

$$
\text { Menurut Sumartono }
$$

menyatakan bahwa konsep perilaku konsumtif amatlah variatif, tetapi pengertian perilaku konsumtif adalah membeli barang atau jasa tanpa pertimbangan rasional atau bukan atas dasar kebutuhan.

\section{Cenderung Malas}

Generasi milineal merupakan gelar yang diperuntukan bagi individu atau kelompok yang menyukai yang bersifat instan dalam segala hal, dalam artian tidak ingin menjadi terbebani oleh waktu dalam mencapai tujuan yang diinginkan. Hal ini menjadi peluang bagi pebisnis khususnya 
yang bergerak pada bisnis online. Dalam sistem online semuanya diterangkan secara detail sehingga tidak membingungkan pelanggan dalam melakukan pemesanan. Dengan semua kemudahan tanpa membingungkan ini, tentunya semua orang menjadi terjerumus akan teknologi yang ditawarkan. Dengan semua kemudahan ini, menjadikan individu menjadi pribadi yang malas berusaha untuk mencapai hasil.

Berdasarkan literatur dari artikel belajarpsikologi.com yang mengutip pendapat dari Zaqeus (2008) Rasa malas diartikan sebagai keengganan seseorang untuk melakukan sesuatu yang seharusnya atau sebaiknya dia lakukan.

\section{Keputusan Mengunakan Go-food}

Berdasarkan literature dari artikel majalahfrancise.com menjelaskan bahwa Setelah sukses mengenalkan bisnis ojek online kepada masyarakat Indonesia, CEO Go-jek Indonesia Nadiem Makarim, mulai melebarkan sayap bisnisnya menyasar bidang lain. Platform yang dikembangkan Go-jek memang memungkinkan hal tersebut. Salah satu layanan barunya adalah Go-food merupakan sebuah fitur layanan Food delivery layaknya delivery order di sebuah rumah makan. Hanya dengan menggunakan smartphone dan membuka fitur Go-food di dalam aplikasi Gojek, konsumen bisa memesan makanan dari restoran yang sudah bekerja sama dengan Gojek. Makanan akan dipesan dan diantar langsung oleh Gojek.

Fitur Go-food yang dikembangkan Gojek jelas menguntungkan semua pihak. Bagi konsumen, bisa dimudahkan dalam hal memesan makanan. Bagi Gojek, bisa menambah pemasukan dengan banyaknya order yang masuk via Go-food. Sedangkan bagi pengusaha usaha, ada potensi kenaikan omset dari layanan Food delivery ini.

Menurut Atmosudirdjo (1987), keputusan adalah suatu pengakhiran dari proses pemikiran tentang suatu problem atau masalah untuk menjawab pertanyaan apa yang harus diperbuat guna mengatasi masalah tersebut dengan menjatuhkan pilihan pada suatu alternatif.
Menurut Kamus Besar Bahasa Indonesia (2002), menggunakan adalah memakai, mengambil manfaatnya, atau melakukan sesuatu dengan.

Berdasarkan definisi di atas, maka dapat ditarik kesimpulan bahwa keputusan menggunakan adalah suatu cara yang digunakan untuk menyelesaikan suatu masalah dengan cara/teknik tertentu untuk melakukan suatu kegiatan.

Adapapun hipotesis pada penelitian ini sebagai berikut:

$\mathrm{H}_{1}$ :User generated content (UGC) berpengaruh positif terhadap keputusan generasi milenial dalam menggunakan aplikasi Go-food.

$\mathrm{H}_{2}$ :Pemanfaatan teknologi dan informasi berpengaruh positif terhadap keputusan generasi milenial dalam menggunakan aplikasi Go-food.

$\mathrm{H}_{3}$ :Perilaku konsumtif berpengaruh positif terhadap keputusan generasi milenial dalam menggunakan aplikasi Go-food.

$\mathrm{H}_{4}$ :Perilaku yang cenderung malas berpengaruh positif terhadap keputusan generasi milenial dalam menggunakan aplikasi Go-food.

$\mathrm{H}_{5}$ :Perilaku konsumtif berpengaruh dominan terhadap keputusan generasi milenial dalam menggunakan aplikasi Go-food.

\section{METODE}

Pendekatan yang digunakan dalam penelitian ini adalah pendekatan deskriftif kuantitatif, yaitu untuk mengetahui bagaimana perilaku generasi milenial dalam menggunakan aplikasi Go-food. Suatu metode pendekatan untuk mengkaji objek penelitian dengan berupaya menjelaskan keterkaitan antara variabel penelitian dengan menggunakan perhitungan statistik dan statistik deskriptif dengan mengunakan analisis deskriftif dan analisis regresi linier berganda.

Penelitian ini dilakukan di Universitas Merdeka Malang dengan sampel 100 Mahasiswa Universitas Merdeka Malang yang telah menggunakan aplikasi Go-food yang tersebar di semua Prodi yang ada 
dengan mengunakan teknik Aksidental Sampling.

\section{HASIL DAN PEMBAHASAN Deskrispsi Responden}
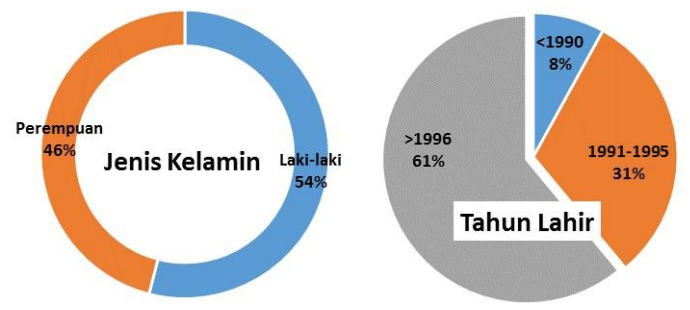

Gambar 1. Jenis Kelamin dan Tahun Kelahiran Rsponden

Sumber : data primer diolah, 2018

Berdasarkan gambar 1 di atas dapat diketahui bahwa mayoritas responden yang menjadi sampel dalam penelitian ini adalah laki-laki yaitu sebanyak 54\%, sedangkan responden perempuannya sebanyak $46 \%$. Adapun responden berdasarkan pada tahun kelahitrannya adalah mayoritas lahir tahun $\geq 1996$ sebayanyak 61\%, kemudian kelahiran tahun 1991-1995 sebanyak 31\% dan yang kelahiran $\leq 1990$ hanya sebanyak $8 \%$. Hal ini menunjukkan bahwa sebagian besar responden adalah laki-laki dengan tahun kelahiran $\geq 1996$.

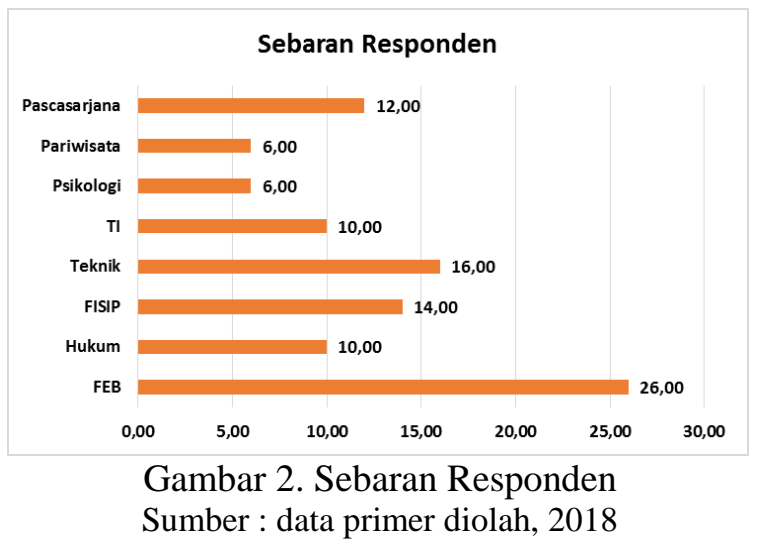

Berdasarkan gambar 2 di atas dapat diketahui bahwa mayoritas sebaran responden yang menjadi sampel dalam penelitian ini berada di Fakultas Ekonomi dan Bisnis sebanyak 26\%, kemudian berada di Fakultas Teknik sebanyak 16\%, ke kemudian berada di Fakultas Ilmu Sosial dan Ilmu Politik sebanyak 14\% dan yang paling sedikit sebaranya berada di Fakultas Psikologi dan Diploma Pariwisata sebanyak 6\%. Hal ini menunjukkan bahwa sebagian besar sebaran responden berada di Fakultas Ekonomi dan Bisnis karena Fakultas Ekonomi dan Bisnis memiliki jumlah mahasiswa yang lebih banyak dibandingkan yang lainnya.

\section{User generated content (UGC)}

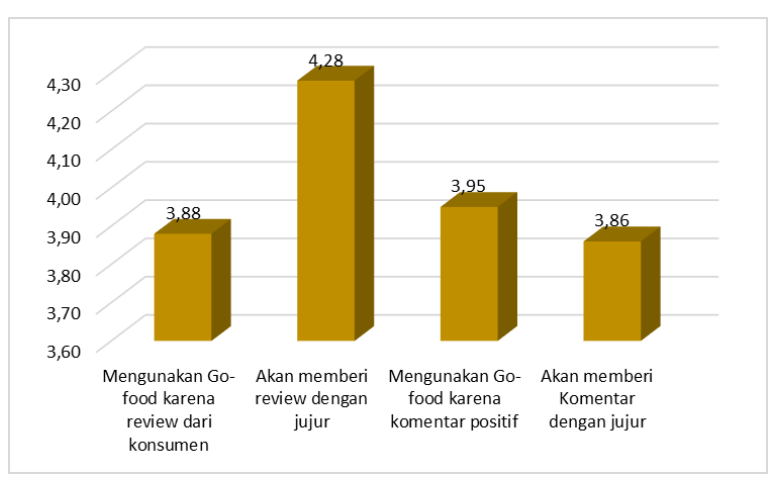

Gambar 3. Nilai Rata-rata untuk Indikator dalam User generated content (UGC) Sumber : data primer diolah, 2018

Berdasarkan gambar 3 di atas dapat diketahui bahwa nilai rata-rata untuk setiap indikator dalam variable user generated content $(U G C)$ yang disebarkan kepada responden menunjukkan bahwa rata-rata dari indikator dalam variable user generated content (UGC) memiliki nilai sebesar 3,99. Hal ini dapat memberikan gambaran bahwa review dan komentar yang terdapat pada aplikasi Go-food memberikan pengaruh terhadap keputusan responden dalam mengunakan aplikasi Go-food dan responden dalam penelitian ini juga dengan senang hati akan memberikan review dan komentar secara jujur terhadap apa yang mereka rasakan setelah mengunakan aplikasi Gofood. 


\section{Memanfaatkan Teknologi dan Informasi}

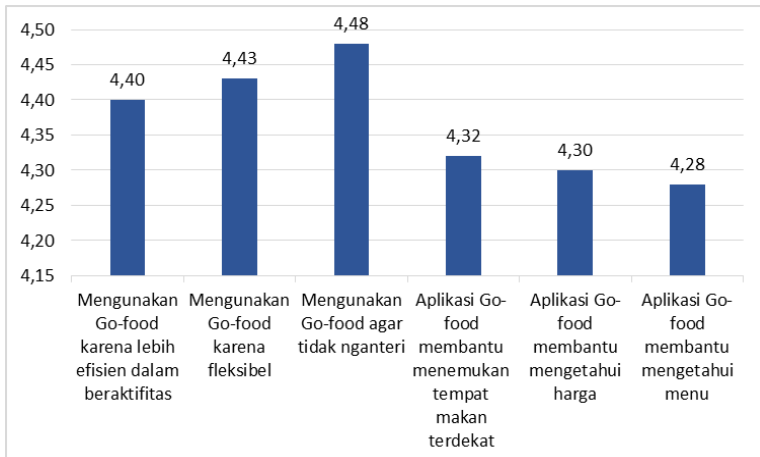

Gambar 4. Nilai Rata-rata untuk Indikator dalam

Memanfaatkan Teknologi dan Informasi

Sumber : data primer diolah, 2018

Berdasarkan gambar 4 di atas dapat diketahui bahwa nilai rata-rata untuk setiap indikator dalam variabel memanfaatkan teknologi dan informasi yang disebarkan kepada responden menunjukkan bahwa ratarata dari indikator dalam variabel memanfaatkan teknologi dan informasi memiliki nilai sebesar 4,37. Hal ini dapat memberikan gambaran bahwa responden mengunakan aplikasi Go-food karena lebih efisien dalam beraktifitas, agar tidak usah menganteri di tempat makan dan juga lebih fleksibel, selain itu aplikasi Go-food juga membantu responden dalam menemukan tempat makan terdekat, mengetahui harga dan menu tanpa harus datang langsung ke tempat makannya.

\section{Konsumtif}

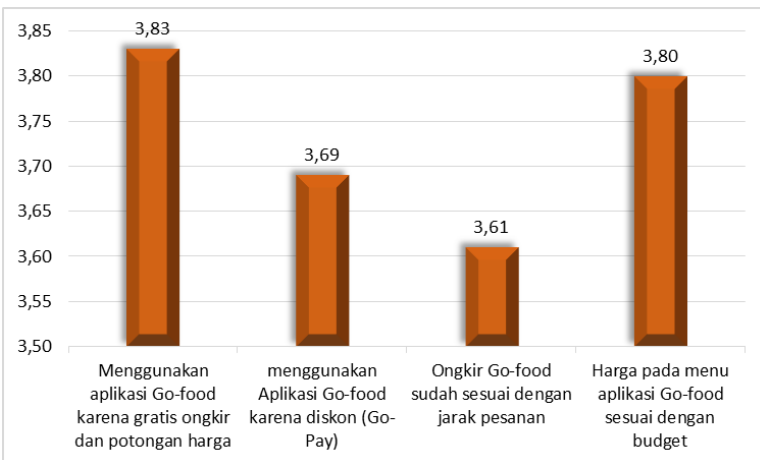

Gambar 5. Nilai Rata-rata untuk Indikator dalam Perilaku Konsumtif

Sumber : data primer diolah, 2018

Berdasarkan gambar 5 di atas dapat diketahui bahwa nilai rata-rata untuk setiap indikator dalam variabel perilaku konsumtif yang disebarkan kepada responden menunjukkan bahwa rata-rata dari indikator dalam variabel perilaku konsumtif memiliki nilai sebesar 3,73. Hal ini dapat memberikan gambaran bahwa salah satu yang menjadi pertimbangan oleh responden dalam menggunakan aplikasi Go-food itu karena gratis ongkos kirim, potongan harga dan mendapatkan diskon karena mengunakan pembayaran dengan Go-Pay, disamping itu ternyata yang menjadi pertimbangan responden dalam mengunakan aplikasi Gofood itu karena bisa memilih harga pada menu aplikasi Go-food sesuai dengan budget yang dimiliki dan biaya ongkir juga sesuai dengan yang tertera dalam aplikasi, sehingga hal tersebut menjadi dorongan responden untuk kembali mengunakan aplikasi Gofood.

\section{Cenderung Malas}

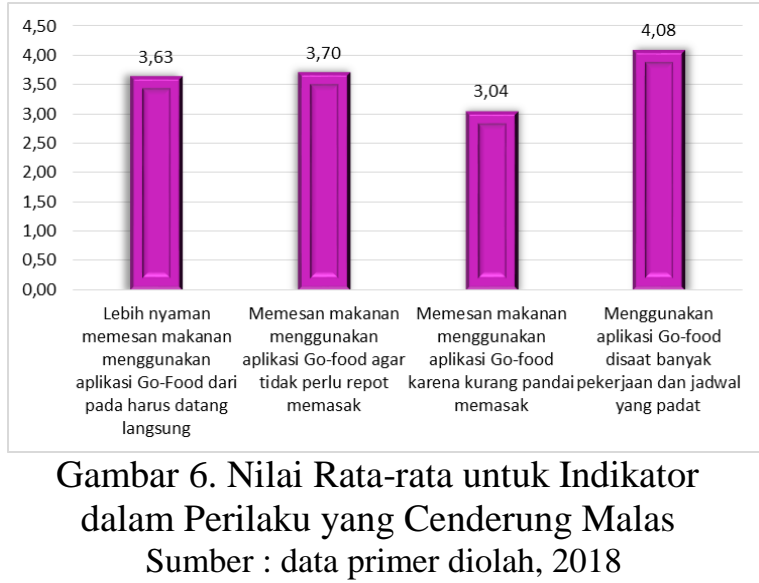

Berdasarkan gambar 6 di atas dapat diketahui bahwa nilai rata-rata untuk setiap indikator dalam variabel perilaku yang cenderung malas yang disebarkan kepada responden menunjukkan bahwa rata-rata dari indikator dalam variabel perilaku yang cenderung malas memiliki nilai sebesar 3,61. Hal ini dapat memberikan gambaran bahwa salah satu yang menjadi alasan responden dalam menggunakan aplikasi Go-food itu karena responden tidak perlu repot-repot lagi untuk memasak dan responden juga tidak perlu untuk datang langsung ketempat makan, kondisi yang seperti ini lah yang 
membuat para pengguna aplikasi Go-food merasa nyaman, lebih-lebih bagi orang yang sedang banyak pekerjaan dan memiliki jadwal yang padat, maka membeli makanan dengan mengunakan aplikasi Go-food menjadi solusi yang terbaik.

\section{Keputusan Menggunakan Aplikasi Go-food}

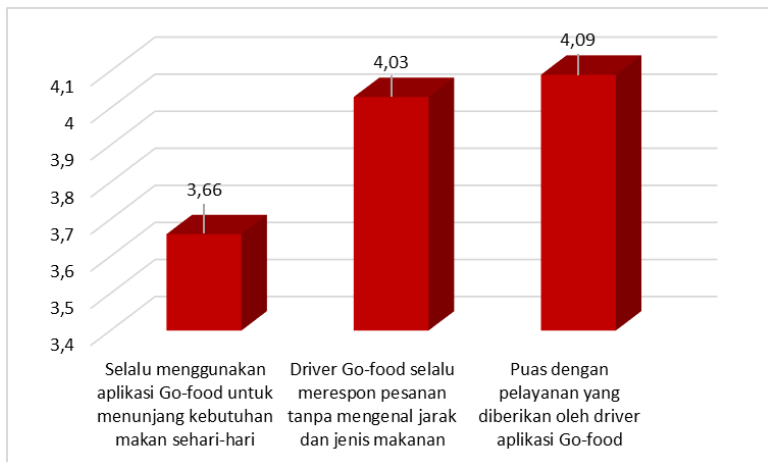

Gambar 7. Nilai Rata-rata untuk Indikator Keputusan dalam Menggunakan Aplikasi Gofood

Sumber : data primer diolah, 2018

Berdasarkan gambar 7 di atas dapat diketahui bahwa nilai rata-rata untuk setiap indikator dalam variabel keputusan dalam menggunakan aplikasi Go-food yang disebarkan kepada responden menunjukkan bahwa rata-rata dari indikator dalam variable keputusan dalam menggunakan aplikasi Gofood memiliki nilai sebesar 3,93. Hal ini dapat memberikan gambaran tentang pertimbangan responden hingga memutuskan mengunakan aplikasi Go-food, diantara pertimbangan tersebut adalah untuk menunjang kebutuhan makan sehari-hari ketika malas keluar, tidak masak atau pada saat memiliki kesibukan yang tidak memungkinkan untuk keluar, disamping itu yang menjadi pertimbangan untuk mengunakan kembali aplikasi Go-food itu adalah karena driver Go-food selalu merespon pesanan tanpa mengenal jarak dan jenis makanan dan pengunan aplikasi Gofood merasa puas dengan pelayanan yang diberikan oleh driver, sehingga penguna aplikasi Go-food tidak segan-segan untuk merekomendasikan kepada temennya untuk mengunakan aplikasi Go-food ketika membutuhkan makanan.

\section{Uji Kelayakan Model}

Uji Validitas ini menunjukkan seberapa jauh instrumen dapat digunakan untuk mengukur apa yang seharusnya diukur (Sugiyono 2007). Dari 21 indikator yang diuji, semua indikator memiliki nilai koefisien korelasi positif dan lebih besar dari $r$ tabelnya, serta probabilitasnya lebih kecil dari $\mathrm{a}=5 \%$, artinya ada hubungan yang signifikan antara skor masing-masing indikator dengan skor total korelasi yang signifikan. Sedangkan Instrumen dinyatakan reliabel jika nilai alpha cronbach yang diperoleh paling tidak mencapai 0,60 (Nurgiyanto, 2000:312). Hasil uji reliabilitas dalam penelitian ini menunjukkan bahwa semua variabel mempunyai nilai alpha cronbach lebih besar dari 0,60, sehingga semua instrument yang digunakan dinyatakan reliabel.

\section{Analisis Regresi Linier Berganda}

Tabel 1. Rekapitulasi Hasil Analisis Regresi Linier Berganda

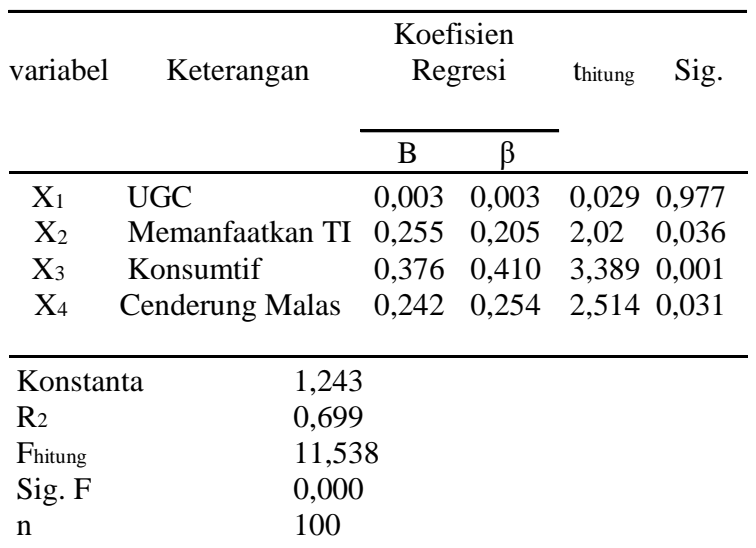

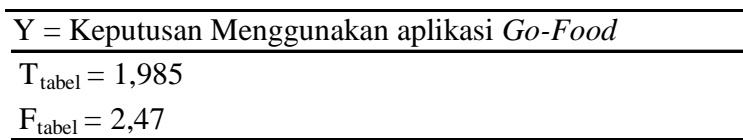

Sumber : data primer diolah, 2018

Berdasarkan pada tabel 1 di atas dapat diperoleh persamaan regresi berganda sebagai berikut : $\mathrm{Y}=1,243+0,003 \mathrm{X}_{1}+$ $0,255 X_{2}+0,376 X_{3}+0,242 X_{4}$. Sedangkan nilai koefisien determinasinya ( $\mathrm{R}$ square) diperoleh sebesar 0,669, hal ini menunjukkan bahwa variabel user generated content $\left(\mathrm{X}_{1}\right)$, memanfaatkan teknologi dan 
informasi $\left(\mathrm{X}_{2}\right)$, konsumtif $\left(\mathrm{X}_{3}\right)$, dan cenderung malas $\left(\mathrm{X}_{4}\right)$ dapat menjelaskan bahwa variasi atau mampu memberikan kontribusi terhadap variabel keputusan dalam mengunakan aplikasi Go-food (Y) sebesar $66,9 \%$, sedangkan sisanya sebesar $33,1 \%$ disebabkan oleh variabel lain yang tidak dimasukkan dalam penelitian ini.

\section{Uji Model}

Uji model dalam penelitian ini mengunakan uji f, berdasarkan uji f pada tabel 1 di atas diketahui bahwa nilai probabilitasnya adalah $(0,000<0,05)$, artinya nilai probabilitasnya lebih kecil dari pada derajat signifikansi yang ditentukan $(0,05)$. Sehingga model regresi linier yang diestimasi layak untuk digunakan.

\section{Hasil Pengujian Hipotesis}

Pengujian hipotesis dalam penelitian ini mengunakan uji $t$, dimana uji t digunakan untuk mengetahui ada tidaknya pengaruh yang signifikan dari variabel bebas terhadap variabel terikat dengan melihat nilai probabilitas $(<0,05)$.

\section{Pengujian Hipotesis I}

Berdasarkan hasil uji t pada tabel 1 dapat diketahui bahwa user generated content (UGC) memiliki pengaruh yang positif namun pengaruh tersebut tidak signifikan terhadap keputusan responden dalam menggunakan aplikasi Go-food. Hal ini dapat dilihat dari nilai probabilitasnya $(>0,05)$ yaitu 0,977. Dengan demikian hipotesis pertama secara statistik tidak dapat diterima atau tidak teruji. Tidak signifikannya peran user generated content terhadap keputusan dalam mengunakan aplikasi Go-food ini sangat wajar. Karena pengunaan aplikasi Go-food tidak menjadikan komen dan review yang terdapat pada menu produk yang ada dalam aplikasi Go-food hal yang utama, mereka lebih mendasarkan pesanan dalam aplikasi Gofood berdasarkan menu yang sedang diinginkan pada saat memesan, selain itu berdasarkan pengalaman mayoritas responden tidak jarang mereka menemukan komen dan review yang tidak sesuai dengan keadaan riilnya.

\section{Pengujian Hipotesis II}

Berdasarkan hasil uji $t$ pada tabel 1 dapat diketahui bahwa pemanfaatan teknologi dan informasi memiliki pengaruh yang positif dan pengaruh tersebut signifikan terhadap keputusan responden dalam menggunakan aplikasi Go-food, hal ini dapat dilihat dari nilai probabilitasnya $(<0,05)$ yaitu 0,036. Dengan demikian hipotesis kedua secara statistik dapat diterima atau teruji. Semua ini tidak terlepas dari perilaku generasi milenial yang sudah menjadikan informasi dan teknologi bagian dari kehidupan mereka, karena mereka lahir dimana akses terhadap informasi, khususnya internet sudah menjadi budaya global, sehingga hal tersebut berpengaruh terhadap perilaku dan nilai-nilai pandangan dan tujuan hidup mereka. Hal ini sejalan dengan penelitian yang dilakukan sebelumnya oleh Hidayatullah, Waris dkk (2018) tentang eksistensi transportasi online (Go-food) terhadap omzet bisnis kuliner di Kota Malang, hasil penelitian ini menyatakan bahwa keberadaan atau eksistensi transportasi online (Go-food) memiliki pengaruh yang positif dan pengaruh tersebut signifikan terhadap omzet bisnis kuliner yang ada di Kota Malang, ini dikarenakan adanya menu Go food di dalam aplikasi Gojek yang memudahkan pelaku bisnis kuliner dalam mempromosikan produknya dengan cepat. Penguna aplikasi Go-food merasa sangat terbantu dengan adanya aplikasi ini karena dengan hanya mengunakan aplikasi Go-food yang ada di hp sudah dapat memesan segala jenis makanan tanpa harus datang langsung ketempat makanan yang akan dibelinya, disamping itu dengan mengunakan aplikasi Go-food penguna merasa terbantu karena dapat mengetahui harga yang pasti dan detail dari produk yang ingin dibelinya.

\section{Pengujian Hipotesis III}

Berdasarkan hasil uji t pada tabel 1 dapat diketahui bahwa perilaku konsumtif 
memiliki pengaruh yang positif dan pengaruh tersebut signifikan terhadap keputusan responden dalam menggunakan aplikasi Go-food, hal ini dapat dilihat dari nilai probabilitasnya $(<0,05)$ yaitu 0,001 . Dengan demikian hipotesis ketiga secara statistik dapat diterima atau teruji. Adapun yang mendorong responden dalam menggunakan aplikasi Go-food itu karena sering gratis ongkos kirim, potongan harga dan mendapatkan diskon, disamping itu juga dapat memilih harga pada menu aplikasi Gofood menyediakan yang sesuai dengan budget yang dimiliki. Sehingga hal tersebut menjadi dorongan responden untuk kembali mengunakan aplikasi Go-food.

\section{Pengujian Hipotesis IV}

Berdasarkan hasil uji t pada tabel 1 dapat diketahui bahwa perilaku yang cendrung malas memiliki pengaruh yang positif dan pengaruh tersebut signifikan terhadap keputusan responden dalam menggunakan aplikasi Go-food. Hal tersebut dapat dilihat dari nilai probabilitasnya $(<0,05)$ yaitu 0,031 . Dengan demikian hipotesis keempat secara statistik dapat diterima atau teruji. Perilaku yang cendrung malas ini juga ikut menjadi salah satu alasan generasi milenial dalam mengunakan aplikasi Go-food karena dengan menggunakan aplikasi Go-food tidak perlu repot-repot lagi untuk memasak dan juga tidak perlu untuk datang langsung ketempat makan, kondisi yang seperti ini membuat generasi milenial merasa nyaman mengunakan aplikasi Go-food.

\section{Pengujian Hipotesis $V$}

Adapun variabel yang paling dominan pengaruhnya terhadap keputusan responden dalam mengunakan aplikasi Go-food adalah perilaku konsumtif dari generasi milenial dibandingkan dengan variabel user generated content, memanfaatkan teknologi informasi dan perilaku yang cenderung malas. Hal ini didasarkan pada variabel bebas yang memiliki nilai koefisien beta paling besar dan signifikan, seperti yang terdapat pada tabel 1 diketahui bahwa nilai koefisien beta terbesar adalah perilaku konsumtif sebesar 0,41. Hal ini berarti bahwa perilaku konsumtif merupakan variabel yang berpengaruh dominan terhadap responden dalam mengunakan aplikasi Gofood. Dengan demikian hipotesis kelima secara statistik dapat diterima atau teruji. Hal ini senada dengan yang disampaikan oleh pengamat digital lifestyle Soebiakto (2018) bahwa generasi milenial adalah generasi yang kreatif dan berani mengambil resiko namun mereka juga sangat konsumtif karena di era generasi milenial ini internet sudah sangat melekat dalam kehidupannya, internet sat ini bukan cuma hanya digunakan untuk komunikasi atau mengkonsumsi konten tapi juga melaukan segala jenis transaksi, dari transportasi, membeli makanan, jalan-jalan, hingga berbelanja pakaian dan kebutuhan sehari-hari.

\section{Kesimpulan}

Berdasar hasil analisa data, maka dapat ditarik kesimpulan yaitu : 1) user generated content (UGC) tidak mempunyai pengaruh signifikan terhadap keputusan generasi milenial dalam menggunakan aplikasi Go-food; 2) pemanfaatan teknologi dan informasi memiliki pengaruh yang positif dan signifikan terhadap keputusan generasi milenial dalam menggunakan aplikasi Go-food; 3) perilaku konsumtif memiliki pengaruh positif dan signifikan terhadap keputusan yang diambil generasi milenial dalam menggunakan aplikasi Gofood; 4) kecenderungan perilaku malas memiliki pengaruh positif dan signifikan terhadap keputusan generasi milenial dalam menggunakan aplikasi Go-food; 5) faktor utama generasi milenial dalam menggunakan aplikasi Go-food adalah perilaku yang konsumtif.

\section{DAFTAR PUSTAKA}

Atmosudirdjo, Prajudi. (1987). Beberapa Pandangan Umum Tentang Pengambilan Keputusan : Decision Making. Jakarta : Ghalia Indonesia.

Belajarpsikologi.com. (2008). Cara mengatasi penyakit malas. 
http://belajarpsikologi.com/caramengatas-penyakit-malas/.

Boston Consulting Group (BCG) bersama University of Berkley. (2011). American Millennials: Deciphering the Enigma Generation.

Cushing, Barry E. (1974). Accounting Information System and Business Organization, Philippines. Addison Wesley Publishing Company.

Departemen Pendidikan Nasional. (2002). Kamus Besar Bahasa Indonesia. Edisi ke-3. Balai Pustaka, Jakarta. Gramedia.

Djoyohadikusumo. (1994). Pengertian Teknologi. Jogyakarta. BPFE.

Hidayatullah. Waris, et al. (2018). Eksistensi Transportasi Online (Go Food) Terhadap Omzet Bisnis Kuliner Di Kota Malang. Seminar Nasional Sistem Informasi 2018 Fakultas Teknologi Informasi. UNMER Malang.

Hitss.com. (2016). Kenali Lebih Jauh Karakteristik Generasi Millennial Lewat 7 Poin Ini. https://www.hitsss. com/kenali-lebih-jauh-karakteristik generasi-millennial-lewat-7-poin-ini/.

Hipwee.com. (2017). Inilah 5 Ciri Generasi Millennial yang Sebenarnya, Sulit sih Buat Nggak Mengakui. https://www.hipwee.com

/feature/inilah-5-ciri-generasimillennial-yang-sebenarnya-sulit-sihbuat-nggak-mengakui/

Lancaster, L. C., \& Stillman, D. (2002). When Generations Collide: Who They Are. Why They Clash. How to Solve the Generational Puzzle at Work. New York: HarperCollins.

Majalahfrancise.com. (2017). Memanfaatkan Go-Food sebagai Layanan Food Delivery.https://www.majalahfranchis e.com/article/306/memanfaatkangofoo d - sebagai - layanan - food delivery.

McLuhan, Marshall. (1962) The Gutenberg Galaxy: The Making of Typographic Man. London \& NewYork. Gingko Press.

Pew Research Center. (2010). Millennials: A Portrait of Generation Next.
Sugiyono. (2010). Metode Penelitian Pendidikan Pendekatan Kuantitatif, kualitatif, dan $R \& D$. Bandung. Alfabeta.

Sumartono. (1998). Pengaruh Terpaan Iklan Shampoo di Televisi Terhadap Sikap dan Perilaku Konsumtif Remaja. Bandung. PPS-Unpad.

Soebiakto, Ben. (2018). Alasan Generasi Milenial Lebih Konsumtif. https:// www.cnnindonesia.com/gayahidup/ 20180418215055-282291845/ alasangenerasi-milenial-lebihkonsumtif

Yuswohady. (2016). Millennial Trends 2016.http://www.yuswohady.com/2016 /01/1 7/millennial-trends-2016/. 